\title{
建築・設備ストックの集積状況を考慮した大阪市の民生業務部門 エネルギー需要モデルの開発と温暖化対策の評価 ENERGY MODELING OF THE COMMERCIAL SECTOR OF OSAKA CITY AND EVALUATION OF ENERGY SAVING MEASURES CONSIDERING THE STOCK OF BUILDINGS AND BUILDING SYSTEMS
}

\author{
山口容平*, 下田吉之**, 水野 稔*** \\ Yohei YAMAGUCHI, Yoshiynki SHIMODA and Minoru MIZUNO
}

\begin{abstract}
This paper describes an energy demand model of the commercial sector of Osaka city. We investigated the distribution of building stock in terms of building size and the utilization of energy saving measures. The modelling methodology is designed to take into account the distribution of building stock and energy saving measures as well as building attributes with a significant influence on the energy consumption. By using the model, we estimated the potential reduction of $\mathrm{CO}_{2}$ emission that can be gained by disseminating energy saving measures and energy efficient lighting devices and heat source machines in the sector.
\end{abstract}

Keywords : Commercial sector, Global warming mitigation, Energy Management, Energy Saving Measures, Simulation 民生業務部門，地球温暖化対策，エネルギー管理，省エネルギー手法，シミュレーション

\section{1.はじめに}

地球温暖化問題等を背景として省エネルギー技術はめざましく進 展している。しかし、民生業務の建築ストックにおいては一様に省 エネルギー対策が実施されているわけではない。資源エネルギー庁 による調査では、中小規模建築においては十分に省エネルギー対策 が行われていないことが報告されている1)。一方、後述するように、 都市全体の建築ストックを見れば中小規模建築の割合は非常に高い。 温暖化対策の推進においては、このような建築ストックおよび省エ ネルギー対策の現状をふまえたうえで、今後の技術的進展、省エネ ルギー対策の普及、新規技術の採用によってもたらされる効用を定 量的に評価することが重要である。

このような背景から、著者らは建築ストックの集積状沉、省エネ ルギー手法の採用実態を調查するとともに、温暖化対応策の設計支 援ツールの開発を目的として、都市のレベルで業務建築ストックに おいて消費されるエネルギー量を定量化するモデル（以下、エネル ギー需要モデルとする）を開発してきた。本モデルは建築ストック の集積状況、省エネルギー対策、加えて、熱源システムの採用状況 などのエネルギー消費に影響を及ぼす要因の現況をデータベース化 し、それらをエネルギー需要の推計值に反映することができる特徴 をもつ。本論文では次の 3 点について報告する。

(1) 東京都区部、多摩 - 島しょ地域、大阪府大阪市、豊中市、愛知 県名古屋市を対象として建築ストックの用途別・規模別の集積
状況を調查し、実存する建築ストックの特徴を明らかにする。 (2) 建築竣工設備データから用途別・規模別に省エネルギー手法の 採用状況を整理し、省エネルギー対策の実施状況を把握する。

(3) 大阪市民生業務部門を対象として開発したエネルギー需要モ デルを用いて、エネルギー消費機器の高効率化、省エネルギー 手法の推進によってもたらされる二酸化炭素排出削減量を定 量化する。

（1）業務建築ストックの集積状況、省エネルギー手法採用状況

中小規模建築とはどの規模の建築を意味するのか明確な定義はな い。仮に 1 万 $\mathrm{m}^{2}$ 未満の建築を中小規模建築とするならば、中小規模 建築は日本の業務建築ストックにおいてが非常に大きな割合を占め る。小松ら 2) は東京都千代田区、港区、新宿区、大東区の事務所建 築、石田 ${ }^{3)}$ は日本全国の業務建築ストックを対象として建築の集積 状況を調查し、 1 万 $\mathrm{m}^{2}$ 未満の建築が延床面積の $50 \%$ 以上を占めるこ とを示している。

省エネルギー対策の実施状況については、資源エネルギー庁 1)が 体系的な調查を行っている。この調査は、全国の業務建築を対象と してアンケートを行ったもので、規模、業種、地域特性が異なる 2136 件の建築から回答を得ている。この結果、大規模な建築ほど設備投 資を伴う省エネルギー対策（空調、照明関連）が積極的に採用され ている傾向があり、中小規模建築では断熱対策をはじめ、各種省工 ネルギー手法の採用率は低い水準にあることが示されている。

\footnotetext{
* 大阪大学大学院工学研究科環境・エネルギー工学専攻 助教・博士 (工学)

* 大阪大学大学院工学研究科環境・エネルギー工学専攻 教授. 工博

*** 大阪大学 名誉教授 $\cdot$ 工博
}

Assistant Prof., Division of Sustainable Energy and Environmental Engineering, Graduate School of Engineering, Osaka University, Dr. Eng.

Prof., Division of Sustainable Energy and Environmental Engineering, Graduate School of Engineering, Osaka University, Dr. Eng.

Prof. Emeritus, Osaka University, Dr. Eng. 
（2）省エネルギー対策の評価手法について

建築における省エネルギーの実施によって得られる効果を定量化 する方法としてシミュレーションが多く用いられている。シミュレ ーションの利点として次のものを挙げることができる。

・建築のエネルギー需要構造を反映し、省エネルギー対策の導入 により電力、冷温熱需要などがどのように変化し、最終的にエ ネルギー消費を変化させるか理解し、定量的に対策導入効果を 把握することができる。

・導入する省エネルギー対策の相互影響を考慮することができる。

・ LED 照明や燃料電池などこれまでに数多く利用例がない手法 について導入効果を推計することができる。

日本建築設備士協会空気調和設備シミュレーション研究会 4)や滝 沢 5) は、標準的な規模や形状、壁の構造、建築設備の構成・仕様を 持つ事務所ビルのモデル（標準問題とも呼ばれる）を開発した。こ れをシミュレーションの入力条件として用いることで、他者とのシ ミュレーション結果の比較が可能になり、シミュレーションの利点 を生かしつつ、汎用性の高い知見が得られるようになった。

標準問題とはストックを代表する建物モデルといえるが、実際の 都市を見れば多様な建築が存在しており、ひとつの標準問題によっ て得られた知見をす心゙ての建築に適用可能であるとは言いがたい。 このような背景から、分析結果の汎用性を確保するため、図 1 に示 す手順によりエネルギー需要を定量化する方法が開発されている。 本研究ではこの方法を建物類型モデルと呼ぶ。

\section{1. 建築ストックの類型化}

エネルギー需要に大きな影響をもつ建物属性によって建築ストックを類型 化する。

\section{2. 代表建物モデルの設計}

各類型を代表する建物モデル(代表建物モデルとする)を設計する

\section{3. 建物類型別エネルギ一需要原単位の定量化}

代表建物モデルを入力条件としてシミュレーションを行い、エネルギー需 要を定量化する。ここで得られたエネルギー需要を原単位化し、代表建 物モデルに対応する建物類型のエネルギー需要原単位とする。

\section{4. 最終エネルギ一需要 (電カ・都市ガス) ・ 二酸化炭素排出量の推計}

各建物類型のエネルギー需要原単位と建築ストック床面積をかけ合わ せ、各建物類型に含まれる建築ストックによって消費されるエネルギー量 を定量化する。得られたエネルギー消費をす心゙ての建物類型について 合計し、都市レベルの最終エネルギー消費量として定量化する。 また、定量化されたエネルギー需要に燃料種別の二酸化炭素排出係数 をかけあわせ、二酸化炭素排出量を定量化する。

図 1 建物類型モデルの概要

この方法では、1）建築のエネルギー需要に大きな影響を及ぼす 要素（用途や規模など）で建築ストックを類型化し、2）建物類型 別に類型に含まれる建築ストックを代表する建物モデル（代表建物 モデルとする）を作成する。次に、3）代表建物モデルを入力条件 としてシミュレーションを行い、エネルギー需要原単位（業務部門 であれば延床面積当たり、住宅部門では世帯当たり)を定量化する。 最後に、4) 各建物類型の建築ストックに対して推計されたエネル ギー需要原単位をかけあわせ、積算し、対象とする建築ストック全 体のエネルギー需要（電力・都市ガス）として定量化する。また、 電力、都市ガスの消費量とそれぞれの二酸化炭素排出係数をかけ合 わせ、二酸化炭素排出量を定量化する。
この方法によって、建築仕様や設備仕様の改善などエンドユース における具体的な変化によってもたらされるエネルギー需要の変化 を定量的に把握することができ、ストック全体での効果（二酸化炭 素排出量の削減など）を定量化することができる ${ }^{677) 。 た と え は ゙ 、 ~}$

Petersdorff ら ${ }^{8)}$ はこのモデル化手法を使用して、EU15 カ国の住宅 ストック、事務所ストックを対象として、気候区分、建築の規模、 種類、年代、断熱性能により 210 の建物モデルを作成し、2006 年 から施行された European Directive on the Energy Performance of Buildings（EPBD）の導入効果、加えて、追加的対策（法規制対 象の拡大）による効果を定量化している。このほか、多様な応用例 がある $6,7,9,9) \sim 13) 。$

日本の業務建築を対象としたモデルも複数開発されている。柳原 ら 14)は、事務所 2 種（規模で分類）、店舗 1 種の代表建物モデルを 作成し省エネルギー手法の導入効果を定量化している。中野ら 15 ) は東京の事務所ストックを対象として 3 つの規模の代表建物モデル を作成し、竹中工務店施工実績から得られた規模別の床面積比率か らエネルギー消費量を積み上げ、複数の省エネルギー手法の導入効 果を定量化している。いずれの研究も既存のエネルギー需要原単位 を用いるのではなく、代表建物モデルを用いたエネルギー需要シミ ユレーションを行っている特徴がある。岩船ら ${ }^{7}$ は東京都の事務所、 商業、宿泊、医療建築ストックについて、用途別に 2 種の代表建物 モデル（規模で分類）を作成し、シミュレーションに基づいてエネ ルギー需要を積み上げている。岩船らのモデル特徴は電源構成モデ ルと統合していることであり、エンドュースにおける省エネルギー 技術の導入が電源構成および系統電源二酸化炭素排出係数に及ぼす 影響を考慮して省エネルギー施策の評価を行っている。新谷ら 16) ・ 川久保ら 17)は、全国の事務所建築ストックを対象として規模につい て 3 種の代表建物モデルを作成し、二酸化炭素排出量の削減ポテン シャルを定量化している。新谷ら、川久保らの研究の特徵は建築の ライフサイクル全体のエネルギー消費、二酸化炭素排出量を算出し ていることであり、建築ストックの長寿命化などライフサイクルを 考慮した温暖化対策の導入効果を定量化することができる。石田 ${ }^{3)}$ は業務建築ストック (事務所、店舗、宿泊、医療、学校、その他) を用途別に建築規模 7 区分、8種の空調熱源システム区分に分類し、 少数のパラメータから月別・時刻別の電力、冷暖房、給湯負荷を算 出する簡易予測モデル 18)に基づいて用途別・規模別・空調熱源シス テム別のエネルギー消費を定量化し、分類別の建築ストック比率を かけ合わせ、日本全国の業務建築ストックから排出される二酸化炭 素排出量を定量化している。石田の特徴は建築仕様、設備仕様の違 いによるエネルギー需要の違いを考慮するために建築ストックを多 数に類型化している点である。

ここまでシミュレーションモデルを用いてエネルギー需要を推計 寸る研究について述べたが、シミュレーションを使用せず、業務建 築の単位床面積当たりの用途別最終需要（冷暖房、給湯、電力など） を設定し、建築ストックの床面積との積によってエネルギー需要、 二酸化炭素排出量を推計する方法がある。本手法では、対策の導入 効果は各用途別最終需要の減少量や減少率として与えられる。モデ ル全体の構造はシンプルであり、国家などの広いスケールで、大幅 に二酸化炭素排出量を削減するために必要な技術的変化を明らかに 寸る目的で使用寸るには大変有用な方法である。代表的なものには 
外岡ら ${ }^{19)}$ 、伊香賀ら ${ }^{20)}$ の研究がある。しかし、モデル上で二酸化炭 素排出量の削減をもたら寸技術的因子の変化を与えるのではなく、 削減量（あるいは削減率）を与えることから、その設定に当てはま らないケースがある場合、結果に大きな誤差が生じる可能性がある。 たとえば、規模や熱源システムなどの条件によって対策の導入効果 が変わる対策や、対策に間接的な影響がある場合（例えば、照明の 高効率化は冷熱需要を減少させ、温熱需要を増加させる）や、対策 の間に相互作用がある場合には誤差が生じると考えられる。これに 対して、シミュレーションによってエネルギー需要を推計する場合、 これらの点を考慮して結果を得ることができる。また、新しい行動 様式 (SOHO 化の進展) が将来普及する状況など、用途別最終需要 が大きく変わるような状況を想定した予測も可能であり、応用範囲 も広い。ただし、シミュレーションによる方法は大量のデータを必 要とする。精度を向上し、機能を拡張寸るためには多様なデータベ ースと、実態を反映したエネルギー需要のシミュレーションモデル が不可欠である。

本研究ではこれまでに蓄積されてきたモデル化手法に関する知見 に基づいて、大阪市民生業務部門のエネルギー需要モデルを開発し た。本モデルは、用途、規模、熱源システムのほか、ゾーニング、 断熱性能、省エネルギー手法の採用状況について建築ストックを類 型化し、データベースを構築してモデルに組み込んでいる。また、 代表建物モデルのエネルギー需要原単位を算出するシミュレーショ ンモデルとして、電力、冷温熱、給湯、蒸気（加湿・消毒など）、ち ゆう房用エネルギーといった用途別最終需要を 1 時間タイムステッ プで詳細に推計するシミュレーションモデルを開発した。これによ り、建築仕様、設備仕様、建築の使われ方（用途など）の違いが個々 の建築のエネルギー消費に及ぼす影響、また、都市における各パラ メータの分布を考慮して都市スケールでエネルギー需要の推計、温 暖化対策の導入効果の推計ができるようになった。

\section{(3) 本論文の構成}

以下では関東、中部、近畿、四国地方に立地する業務建築の省エ ネルギー手法の採用状況を推計した結果を示す。次に、エネルギー 需要モデルの構成を説明し、エネルギー需要の推計結果を示す。最 後に大阪市民生業務部門を対象として複数の省エネルギー対策導入 ケースを想定し、都市スケールで二酸化炭素排出量削減ポテンシャ ルを推計する。結果から温暖化対策の推進における課題を議論する。

\section{2. 業務建築ストック集積状況、省エネルギー手法採用状況の把握 （1）業務建築ストックの集積状況}

東京都区部、多摩・島しょ地域、大阪府大阪市、愛知県名古屋市 を対象に、規模別に業務建築の床面積比率を推計した。推計には表 1 に示寸データを用いた。各データは、航空写真と現地調查に基づ いて作成されたものであり、建築一棟を単位とする情報が集計され ている。本研究では、建築面積を基準階面積と仮定し、建築面積と 地上階数の積によって延床面積を与えた。この仮定によって高層建 築の延床面積を過大に算出する可能性があるが、非課税建築を含め、 業務建築の用途別・規模別の床面積を把握することが可能である。

結果を図 2 に示す。図に示した業務部門床面積の合計は 311 百万 $\mathrm{m}^{2}$ であり、2001 年における日本全国の業務部門建築の床面積推計值 25) $\left(1,686\right.$ 百万 $\left.\mathrm{m}^{2}\right)$ と比較すると、日本の業務建築の $18 \%$ を占める。
図からわかるように、延床面積 $2,000 \mathrm{~m}^{2}$ 未満の建築は全業務ストッ クの 30〜 40\%を占め、1 万 $\mathrm{m}^{2}$ 未満では約 $60 \%$ ～70\%を占める。

表 1 建築ストック調査に用いたデータ

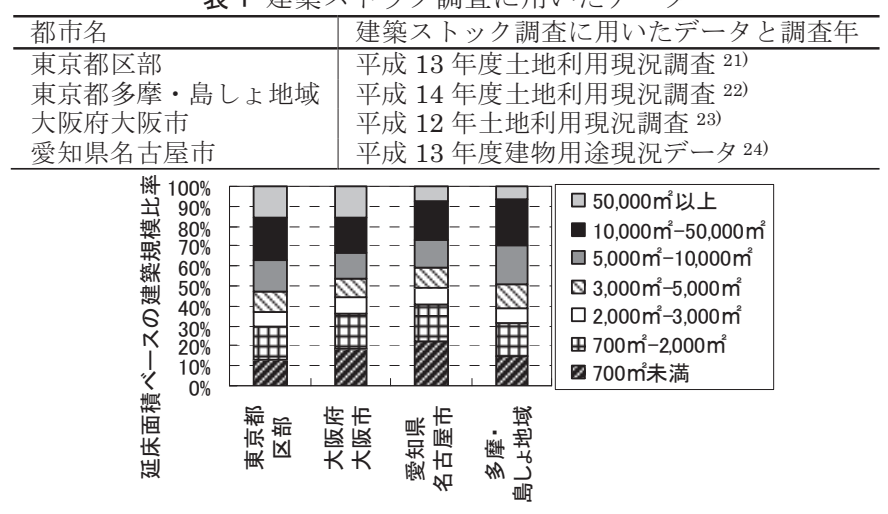

図 2 規模別の建築ストック比率

\section{（2）省エネルギー手法の採用状況}

業務建築における省エネルギー手法の採用状沉を把握するため、 社団法人空気調和・衛生工学会の竣工設備データ 26)を用いて、用途 別・規模別に全熱交換器、外気冷房、VAV、VWV、大温度差搬送の 5 つ省エネルギー手法の採用状況を集計した。竕工設備データは 1993 年から 2006 年までのもので、このうち、関東、中部、近畿、 四国地方に立地する業務建築（事務所 1682 件、商業 632 件、宿泊 352 件、医療 1209 件）をサンプルとして採用した。本竣工設備デ 一タは 5 つの手法に加えて、熱回収、自然エネルギー利用、インバ ータ制御、蓄熱、コージェネレーションという手法の採否のデータ を含む。しかし、本研究のエネルギー需要モデルでは熱回収システ ムを考慮できていないことからこれを無視した。また、自然エネル ギー利用とインバータ制御は記述された手法がどのような手法を指 寸のか明確でないことから無視した。また、後述するエネルギー需 要モデルでは蓄熱とコージェネレーションシステムの採用、竣工設 備データに含まれていない高効率照明の採用、外壁の断熱化を別途 考慮した。ここで対象とする 5 つの手法は省エネルギー手法全般か らすると限定的であるが、いずれの手法も広く使用されているもの であり、業務建築における省エネルギー手法の採用状況を理解する うえでは十分な結果を得ることができると考えられる。

本研究では用途に加えて建築の規模（延床面積）、空調システムの 種類（セントラル方式、あるいは、個別分散型空調システム）によ ってサンプルを分類し、それぞれの分類について省エネルギー手法 の採用状況を集計した。集計ではすべての省エネルギー手法の組み 合わせを列挙し、各省エネルギー手法の組み合わせが採用されてい る建築数の比率を算出した。ただし、集計に使用した規模の区分は、 第 3 節に説明寸る大阪市の建築ストックの規模区分を用いた。

図 3 に建物途別の省エネルギー手法採用状況を集計した結果を示 す。図からわかるように、建築規模が大きくなるにつれて、多様な 省エネルギー手法が導入される傾向を見ることができる。業務建築 ストックの $50 \%$ 以上を占める中小規模建築では省エネルギー手法 の採用数が小さい。また、個別分散型空調システムを採用している 建築はセントラル方式を採用している建築と比較して省エネルギー 手法の採用数が少ない。用途別に比較すると、事務所建築の省エネ ルギー手法採用数が比較的大きいのに対して、商業建築は省エネル ギー手法の採用数が少ない。 


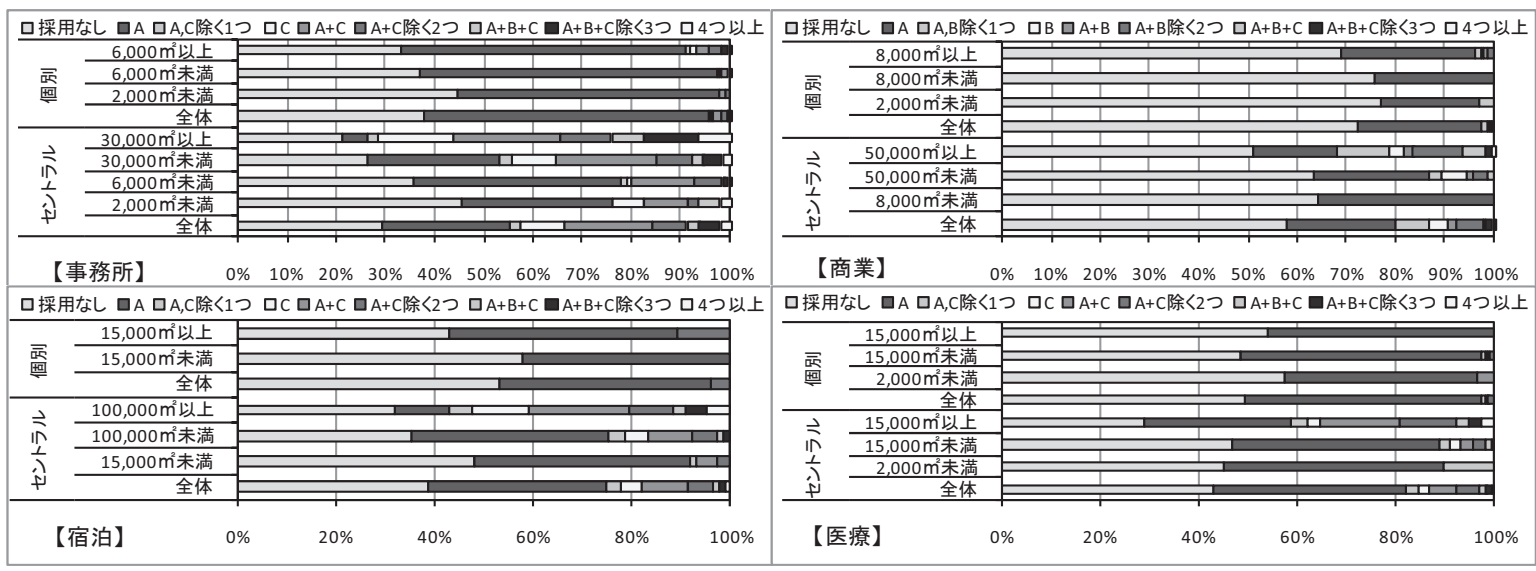

図 3 用途別・規模別省エネルギー手法採用状沉 (A:全熱交換器, $\mathrm{B}$ :外気泠房, $\mathrm{C}: \mathrm{VAV}$ 搬送, $\mathrm{D}: \mathrm{VWV}$ 搬送, $\mathrm{E}$ : 大温度差搬送)

表 2 大阪市業務建築ストックの類型化

\begin{tabular}{|c|c|c|c|c|c|c|}
\hline 用途 & 規模区分 & CL1 & CL2 & CL3 & CL4 & CL5 \\
\hline 事務所 & $\begin{array}{l}\text { 延床面積区分範囲 } \\
\text { 床面積比率 [\%] } \\
\text { 延床面積 }\left[\mathrm{m}^{2}\right] \\
\text { 基準階床面積 }\left[\mathrm{m}^{2}\right] \\
\text { 階数 }\end{array}$ & $\begin{array}{l}700 \mathrm{~m}^{2} \text { 未満 } \\
17.9 \\
385 \\
128 \\
3\end{array}$ & $\begin{array}{l}700 \mathrm{~m}^{2}-2,000 \mathrm{~m}^{2} \\
19.4 \\
1,257 \\
314 \\
4\end{array}$ & $\begin{array}{l}2,000 \mathrm{~m}^{2}-6,000 \mathrm{~m}^{2} \\
21.6 \\
3,635 \\
606 \\
6\end{array}$ & $\begin{array}{l}6,000 \mathrm{~m}^{2}-30,000 \mathrm{~m}^{2} \\
22.8 \\
14,034 \\
1,559 \\
9\end{array}$ & $\begin{array}{l}30,000 \text { 以上 } \\
18.4 \\
145,998 \\
5,615 \\
25\end{array}$ \\
\hline 商業: 店舗 & $\begin{array}{l}\text { 延床面積区分範囲 } \\
\text { 床面積比率 [\%] } \\
\text { 延床面積 }\left[\mathrm{m}^{2}\right] \\
\text { 基準階床面積 }\left[\mathrm{m}^{2}\right] \\
\text { 階数 }\end{array}$ & $\begin{array}{l}500 \mathrm{~m}^{2} \text { 未満 } \\
20 \\
245 \\
122 \\
2\end{array}$ & $\begin{array}{l}500 \mathrm{~m}^{2}-2,000 \mathrm{~m}^{2} \\
20 \\
1,081 \\
541 \\
2\end{array}$ & $\begin{array}{l}2,000 \mathrm{~m}^{2}-8,000 \mathrm{~m}^{2} \\
19 \\
4,137 \\
1,379 \\
3\end{array}$ & $\begin{array}{l}8,000 \mathrm{~m}^{2}-50,000 \mathrm{~m}^{2} \\
22 \\
23,614 \\
4,723 \\
5\end{array}$ & $\begin{array}{l}50,000 \mathrm{~m}^{2} \text { 以上 } \\
19 \\
170,619 \\
15,511 \\
11\end{array}$ \\
\hline 商業:飲食 & $\begin{array}{l}\text { 延床面積区分範囲 } \\
\text { 床面積比率[\%] } \\
\text { 延床面積 }\left[\mathrm{m}^{2}\right] \\
\text { 基準階床面積 }\left[\mathrm{m}^{2}\right] \\
\text { 階数 }\end{array}$ & $\begin{array}{l}500 \mathrm{~m}^{2} \text { 未満 } \\
37 \\
261 \\
87 \\
3\end{array}$ & $\begin{array}{l}500 \mathrm{~m}^{2}-2,000 \mathrm{~m}^{2} \\
35 \\
1,037 \\
259 \\
4\end{array}$ & $\begin{array}{l}2,000 \mathrm{~m}^{2}-3,000 \mathrm{~m}^{2} \\
8 \\
2,444 \\
489 \\
5\end{array}$ & $\begin{array}{l}3,000 \mathrm{~m}^{2}-6,000 \mathrm{~m}^{2} \\
11 \\
4,292 \\
613 \\
7\end{array}$ & $\begin{array}{l}6,000 \mathrm{~m}^{2} \text { 以上 } \\
9 \\
22,106 \\
2,010 \\
11\end{array}$ \\
\hline 宿泊 & $\begin{array}{l}\text { 延床面積区分範囲 } \\
\text { 床面積比率[\%] } \\
\text { 延床面積 }\left[\mathrm{m}^{2}\right] \\
\text { 基隻階床面積 }\left[\mathrm{m}^{2}\right] \\
\text { 階数 }\end{array}$ & $\begin{array}{l}1,100 \mathrm{~m}^{2} \text { 未満 } \\
6.7 \\
649 \\
162 \\
4\end{array}$ & $\begin{array}{l}1,100 \mathrm{~m}^{2}-2,000 \mathrm{~m}^{2} \\
6.2 \\
1,509 \\
302 \\
5\end{array}$ & $\begin{array}{l}2,000 \mathrm{~m}^{2}-15,000 \mathrm{~m}^{2} \\
19.1 \\
5,963 \\
852 \\
9\end{array}$ & $\begin{array}{l}15,000 \mathrm{~m}^{2}-100,000 \mathrm{~m}^{2} \\
27.1 \\
56,329 \\
5,121 \\
19\end{array}$ & $\begin{array}{l}100,000 \mathrm{~m}^{2} \text { 以上 } \\
40.9 \\
209,407 \\
8,054 \\
28\end{array}$ \\
\hline 医療 & $\begin{array}{l}\text { 延床面積区分範囲 } \\
\text { 床面積比率[\%] } \\
\text { 延床面積 }\left[\mathrm{m}^{2}\right] \\
\text { 基隻階床面積 }\left[\mathrm{m}^{2}\right] \\
\text { 階数 }\end{array}$ & $\begin{array}{l}500 \mathrm{~m}^{2} \text { 未満 } \\
20.0 \\
264 \\
132 \\
2\end{array}$ & $\begin{array}{l}500 \mathrm{~m}^{2}-2,000 \mathrm{~m}^{2} \\
19.6 \\
1,084 \\
361 \\
3\end{array}$ & $\begin{array}{l}2,000 \mathrm{~m}^{2}-6,000 \mathrm{~m}^{2} \\
18.9 \\
3,788 \\
947 \\
4\end{array}$ & $\begin{array}{l}6,000 \mathrm{~m}^{2}-30,000 \mathrm{~m}^{2} \\
19.6 \\
13,371 \\
2,228 \\
6\end{array}$ & $\begin{array}{l}30,000 \mathrm{~m}^{2} \text { 以上 } \\
21.8 \\
90,025 \\
6,430 \\
14\end{array}$ \\
\hline
\end{tabular}

3. 都市スケールのエネルギー需要モデルの開発

図 1 に示した建物類型モデルの構築手順に基づき、大阪市の業務 建築のエネルギー需要モデルを開発した。以下では、建築ストック の類型および類型別の床面積比率の算出方法と、代表建物モデルを 入力としてエネルギー需要を推計するシミュレーションモデルの概

要、大阪市全体のエネルギー需要推計結果を述べる。

\section{1 業務建築ストックの類型化および代表建物モデルの作成}

本研究では(1)用途 (5 用途)、(2)規模（5 分類）、(3)ゾーニング (9 種)、(4)断熱の有無（2 種）、(5)採用している熱源システム（8 シス テム）および6)省エネルギー手法（5 水準）に基づいて業務建築ス トックを類型化した。図 4 に本研究で想定した各要素の関係性を示 す。建築の規模の分布は用途により異なり、ゾーニング、熱源シス テムの採用比率は用途・規模に依存するものとした。また、省エネ ルギー手法の採用比率は熱源システム（セントラル空調方式、ある いは、個別分散型空調方式）によって異なるものとした。断熱の採 用比率については用途・規模等との関係性を示寸資料がなかったこ とから、一定の比率を与えるものとした。この結果、業務建築ス卜 ックは合計 18,000 の区分に分類される。各区分の床面積の比率は、 (1)から (5)の各分類要素の床面積比率の積によって与えられる。

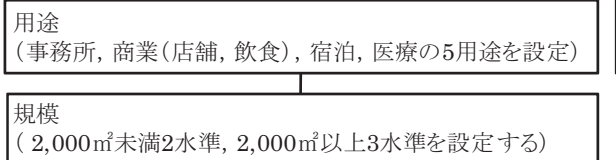

\section{断熱の有無} ( 2 水準 $)$

断熱の採用の有無は 用途や規模によらず $\left(2,000 \mathrm{~m}^{2}\right.$ 未満 2 水準, $2,000 \mathrm{~m}^{2}$ 以上 3 水準を設定する $)$ 2水準を想定した。

\section{熱源システム}

(8種の冷温熱源機器、コージェネレーション、蓄熱槽の 組み合わせを設定)

省エネルギー手法

(第2章で調査した省エネルギー手法の組み合わせにつ いて5つの水準を設定し、5段階で省エネルギー手法の 採用数が増えるように設定）

図 4 建築ストックの類型化に用いた要素とその関係性

\section{（1）用途および規模によるストックの類型}

ここでは事務所、商業、宿泊、医療の各建築ストックを建築の規 模によって 5 つの区分に類型化した。以下ではこの区分を「規模区 分」とし、CL1（最も規模が小さい区分）から CL5（最も大きい区 分）として表示する。

ストックの類型に用いたデータは、前述の大阪府大阪市の土地利 用現況調查 ${ }^{23)}$ の建物別のデータである。まず、すべての建物を用途 で分類し、次に、省エネルギー法の適用範囲である延床面積 2,000 
$\mathrm{m}^{2}$ を境界としてサンプルを 2 つに分けた。さらに、 $2,000 \mathrm{~m}^{2}$ 末満の 業務建築を 2 つ、2,000 $\mathrm{m}^{2}$ 以上の業務建築を 3 つの規模区分に分類 した。ここでの分類は各規模区分の床面積合計值が均等になる延床 面積を求め、その床面積を境界として規模区分を決定した。表 2 に この方法で得られた大阪市業務建築の規模区分および各規模区分に 含まれる建築ストックの割合を示す。ただし、各規模区分の境界と なる床面積は、表 2 (用途別の床面積区分）に示寸ように区切りの よい数字とした。

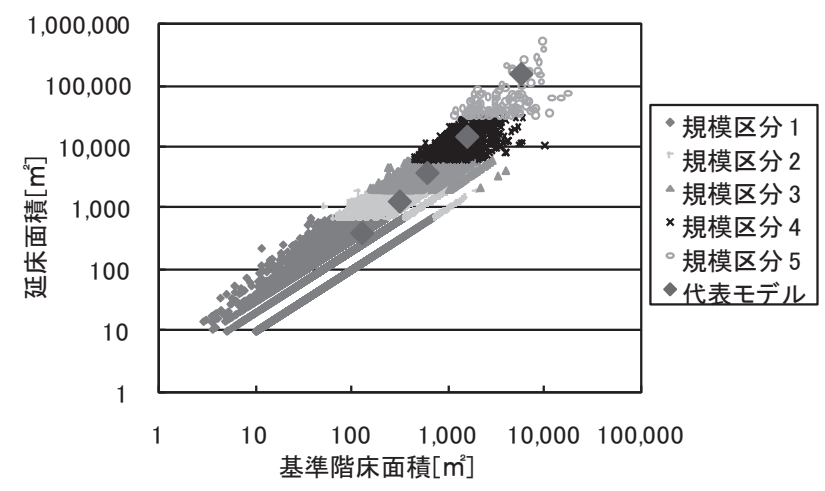

図 5 大阪市の事務所建築の床面積分布と 代表建物モデルの延床面積及び基準階床面積

\section{（2）用途別・規模別の代表建物モデルの設計}

用途・規模の各類型について、代表建物モデルの延床面積、基準 階床面積、階数を決定する。延床面積および基準階床面積について、 延床面積に基づく重みづけ平均を行い、代表建物モデルの延床面積、 基準階床面積とした。次に、得られた基準階床面積によって延床面 積を除し、端数を四捨五入した数值を代表建物モデルの階数とした。 最後に、延床面積を階数で割り、代表建物モデルの基準階床面積と した。結果を表 2 に併せて示す。例として、図 5 に事務所建築の延 床面積、基準階床面積の分布、代表建物モデルの延床面積、基準階
床面積を示す。

\section{（3）建物モデルの階層別用途の設定}

業務建築は複数の用途が混在する場合が多い。このような用途の 混在を考慮し、代表建物モデルでは階層別に用途を設定した。

建築設備士協会の竣工設備データ $\mathrm{ELPAC}^{27)}$ は、建築の詳細用途 別の床面積比率を集計している。詳細用途とは、事務所、物販店舗、 飲食店舗、貸しホール、貸し会議室、運動施設、娛楽・共用施設、 電算機室、展示スペース、社員食堂、レストラン、宴会場、結婚式 場、医療施設病棟部・外来部・診療部・供給部・管理部、その他で ある。このデータを表 2 に示した規模区分について再集計した。結 果を表 3 に示す。これに基づいて、各用途の代表建物モデルの階層 別の用途を設定した。設定の概要を表 3 に併せて示している。
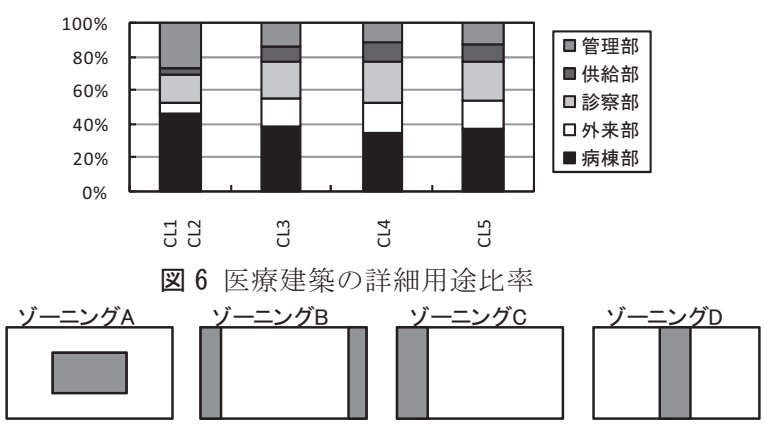

図 7 ゾーニングの種類（灰色部分は非空調室を表す）

(4) ゾーニング

ゾーニングとして図 7 に示す種類を考慮し、とりうる方位を勘案 し、合計 9 種のゾーニングを想定した。

各規模区分の面積比率は、規模区分 CL1、CL2 については片側コ ア（図 7 の C) のみとし、1/4 ずつの比率とした。宿泊、医療では、 規模区分 CL3 CL5 ではすべてセンターコア（図 7A）とした。こ の理由は、客室、病棟に空を配置する建物が多いためである 28)299。

表 3 竣工設備データによる用途別床面積の集計結果と代表建物モデルの用途の設定

\begin{tabular}{|c|c|c|c|}
\hline 用途 & 規模区分 & 竕工設備データの集計結果 & 代表建物モデルの用途の設定 \\
\hline \multirow{3}{*}{$\begin{array}{l}\text { 事 } \\
\text { 務 } \\
\text { 所 }\end{array}$} & CL1-3 & 95\%の床面積が事務所のみで構成される。 & すべての階層を事務所用途とする。 \\
\hline & CL4 & $\begin{array}{l}8 \% \text { の床面積が異なる用途で構成される。内訳は飲食店舗 } \\
52 \% \text { 、物販店舗 } 15 \% \text { 、電算施設 } 15 \% \text { である。 }\end{array}$ & $1 \mathrm{~F}$ (延床面積の $11 \%$ に相当)に飲食店舗が配置されているものとする。 \\
\hline & CL5 & $\begin{array}{l}\text { 約 } 10 \% \text { がオフィス以外の用途で構成される。その内訳は、 } \\
\text { 物販店舗 } 22 \% \text { 、飲食店舗 } 35 \% \text { 、貸ホール・貸会議室 } \\
20 \% \text { 、電算機室 } 8 \% \text { である。 }\end{array}$ & 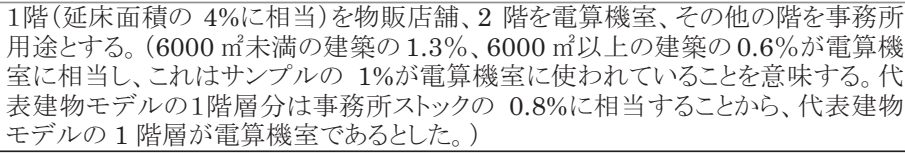 \\
\hline \multirow[t]{3}{*}{$\begin{array}{l}\text { 店 } \\
\text { 舗 }\end{array}$} & CL1-3 & $\begin{array}{l}72 \% か ゙ \text { 物販店舗であり、10\%が飲食店舗、その他は事務 } \\
\text { 室などで構成されている。 }\end{array}$ & $\begin{array}{l}\text { CL1、CL2 は全ての階層を物販店舗とする。CL3 は } 1 \text { 階部分を飲食店舗とし、そ } \\
\text { の他を物販店舗とする。 }\end{array}$ \\
\hline & CL4 & $\begin{array}{l}73 \% \text { が物販店舗であり、8\%が飲食店舗、その他は事務室 } \\
\text { などで構成されている。 }\end{array}$ & 1 階部分を飲食店舗とし、その他を物販店舗とする。 \\
\hline & CL5 & $\begin{array}{l}58 \% \text { が物販店舗であり、10\%が飲食店舗、8\%が事務室、 } \\
\text { その他は運動施設やアトリムなどで構成されている。 }\end{array}$ & 最上階 (11 階)を飲食店舗とし、10 階部分を事務所用途とする。 \\
\hline $\begin{array}{l}\text { 飲 } \\
\text { 食 }\end{array}$ & CL1-5 & $\begin{array}{l}\text { 飲食店舗が主用途である建物は } 17 \text { 件のみであったが、い } \\
\text { ずれの規模で集計しても、 } 80 \% \text { 強が飲食店舗であった。 }\end{array}$ & 用途の混合はなく、すべてが飲食店舗とする。 \\
\hline \multirow[t]{3}{*}{$\begin{array}{l}\text { 宿 } \\
\text { 泊 }\end{array}$} & CL1-3 & $\begin{array}{l}13 \% \text { 床面積が客室以外で構成される。そのうち、最も床 } \\
\text { 面積が大きいのは寔場の分類である。宴会場、レストラン } \\
\text { など飲食関連の床面積は } 80 \% \text { 超える。 }\end{array}$ & 1階層目をフロントとレストラン・宴会場とし、それ以外を客室とする。 \\
\hline & CL4 & $\begin{array}{l}\text { 15\%の床面積が客室以外であり、大部分が飲食関連の床 } \\
\text { 面積である。 }\end{array}$ & $\begin{array}{l}\text { 代表建物モデルの } 15 \% \text { の床面積は } 3 \text { 階層分に相当する (全 } 19 \text { 階層)。1F をロビ } \\
\text { 一、事務室、レストランとし、 } 2 \mathrm{~F} \text { を宴会場、最上階をレストランとする。 }\end{array}$ \\
\hline & CL5 & $\begin{array}{l}\text { 客室以外の床面積は } 27 \% \text { 占める。客室以外の床面積の } \\
35 \% \text { 物販店舗が占める。このほかは宴会場、レストラン、 } \\
\text { 結婚式場、厨房などが占める。 }\end{array}$ & $\begin{array}{l}\text { 代表建物モデルの } 27 \% \text { の床面積は } 7 \text { 階層分に相当する(全 } 28 \text { 階層)。1F、2F } \\
\text { を物販店舗とする。 } 3 \mathrm{~F}-5 \mathrm{~F} \text { を宴会場、最上階 } 2 \text { 階層をレストランとする。 }\end{array}$ \\
\hline \multirow{5}{*}{$\begin{array}{l}\text { 医 } \\
\text { 療 }\end{array}$} & CL1 & \multirow{5}{*}{$\begin{array}{l}\text { 医療建築の竣工設備データでは病棟部、外来部、診察 } \\
\text { 部、供給部、管理部、その他の区分で床面積が与えられて } \\
\text { いる。「の他」を除いて規模区分別に比率を算出した。結 } \\
\text { 果を図 } 6 \text { に示す。この区分に忘じて代表建物モデルの各 } \\
\text { 階層の用途を決定した。 }\end{array}$} & 病床のない診療所を想定。1F を受付ロビーと管理事務所、2F を診療部とする。 \\
\hline & CL2 & & $\begin{array}{l}\text { 病床のある診療所を想定。1 } \mathrm{F} \text { を受付・管理事務所、診療部、 } 2 \mathrm{~F} \text { を診療部、 } 3 \mathrm{~F} \text { を } \\
\text { 病棟部とする。 }\end{array}$ \\
\hline & CL3 & & 1F 部分を受付・管理事務所、診療部、2F を診療部、3F、4F を病棟部とする。 \\
\hline & CL4 & & 1Fを受付・管理事務所とし、2F～4F を診療部、5F、6F を病棟部とする。 \\
\hline & CL5 & & $\begin{array}{l}\text { 地下 } 2 \text { 階を駐車場、倉庫、機械室とし、地下 } 1 \text { 階を供給部、地上 } 1 \text { 階をロビー、管 } \\
\text { 理事柔所、 } 2 \mathrm{~F} \sim 5 \mathrm{~F} \text { 診療部、 } 6 \mathrm{~F} \sim 12 \mathrm{~F} \text { を病棟部とする。 }\end{array}$ \\
\hline
\end{tabular}




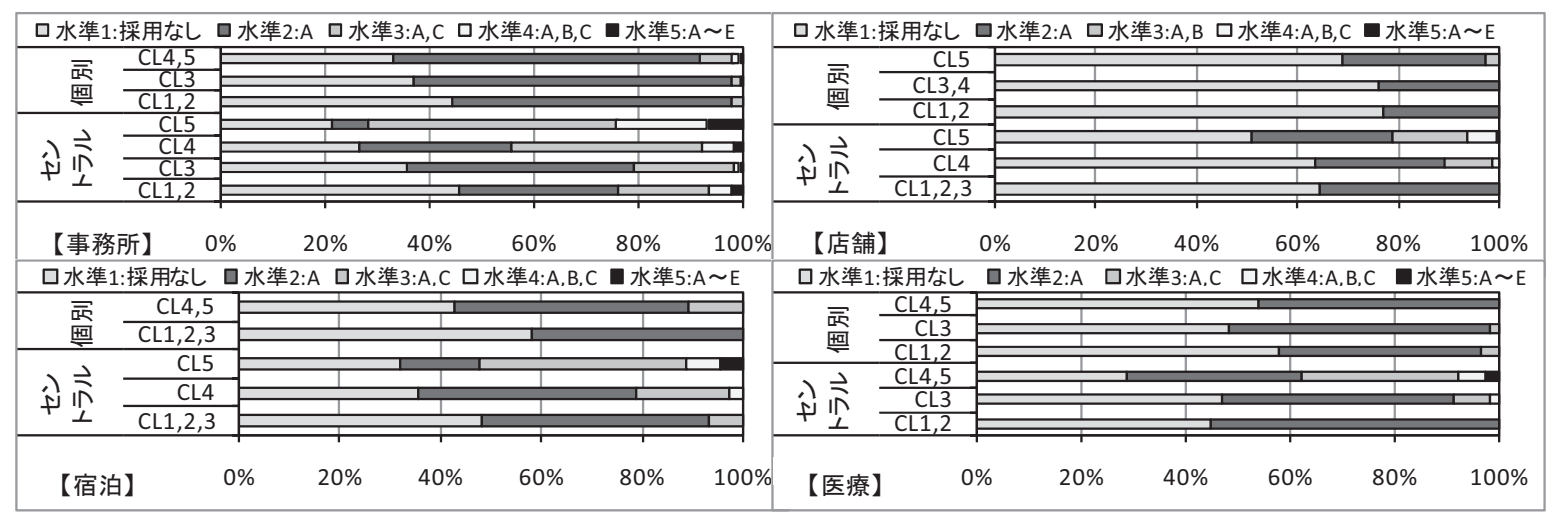

図 8 用途別・規模別省エネルギー手法採用比率 (A:全熱交換器, B:外気冷房， C: VAV 搬送， D:VWV 搬送， E: 大温度差搬送）
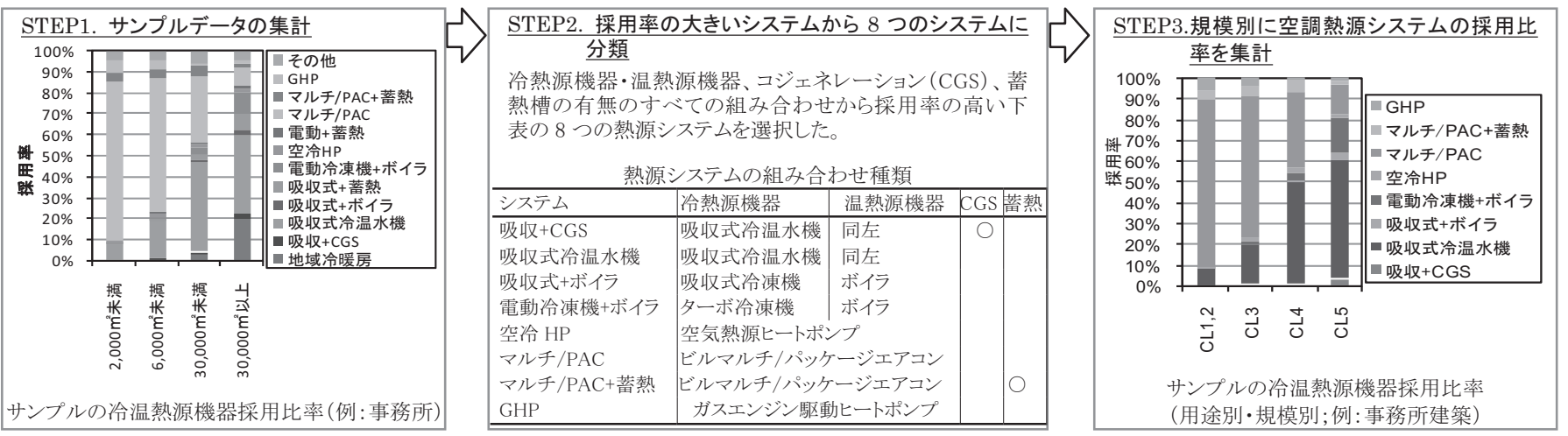

図 9 熱源システムの組み合わせの集計方法

表 4 用途別・規模別熱源システム採用率

\begin{tabular}{|c|c|c|c|c|c|c|c|c|c|c|c|c|c|c|c|}
\hline 用途 & \multicolumn{4}{|c|}{ 事務所 } & \multicolumn{4}{|c|}{ 商業:店舗 } & \multicolumn{4}{|c|}{ 宿泊 } & \multicolumn{3}{|c|}{ 医療 } \\
\hline 熱源システム組合せ & CL1,2 & CL3 & CL4 & CL5 & CL1,2 & CL3 & CL4 & CL5 & CL1,2 & CL3 & CL4 & CL5 & CL1,2 & CL3 & CL4,5 \\
\hline 吸収+CGS & $0 \%$ & $1 \%$ & $1 \%$ & $3 \%$ & $0 \%$ & $0 \%$ & $1 \%$ & $4 \%$ & $0 \%$ & $1 \%$ & $3 \%$ & $8 \%$ & $0 \%$ & $2 \%$ & $21 \%$ \\
\hline 吸収式冷温水機 & $8 \%$ & $19 \%$ & $50 \%$ & $57 \%$ & $9 \%$ & $24 \%$ & $52 \%$ & $72 \%$ & $45 \%$ & $49 \%$ & $66 \%$ & $60 \%$ & $18 \%$ & $46 \%$ & $56 \%$ \\
\hline 吸収式+ボイラ & $0 \%$ & $0 \%$ & $0 \%$ & $3 \%$ & $0 \%$ & $0 \%$ & $1 \%$ & $1 \%$ & $0 \%$ & $1 \%$ & $2 \%$ & $21 \%$ & $0 \%$ & $1 \%$ & $16 \%$ \\
\hline 電動冷凍機+ボイラ & $0 \%$ & $1 \%$ & $4 \%$ & $17 \%$ & $2 \%$ & $2 \%$ & $4 \%$ & $9 \%$ & $7 \%$ & $9 \%$ & $5 \%$ & $5 \%$ & $5 \%$ & $1 \%$ & $0 \%$ \\
\hline 空冷 HP & $1 \%$ & $2 \%$ & $2 \%$ & $2 \%$ & $0 \%$ & $0 \%$ & $0 \%$ & $0 \%$ & $0 \%$ & $8 \%$ & $4 \%$ & $0 \%$ & $0 \%$ & $1 \%$ & $2 \%$ \\
\hline マルチ/PAC & $80 \%$ & $68 \%$ & $37 \%$ & $13 \%$ & $76 \%$ & $57 \%$ & $30 \%$ & $8 \%$ & $45 \%$ & $30 \%$ & $18 \%$ & $5 \%$ & $63 \%$ & $34 \%$ & $4 \%$ \\
\hline マルチ/PAC+蓄熱 & $4 \%$ & $4 \%$ & $6 \%$ & $2 \%$ & $0 \%$ & $5 \%$ & $3 \%$ & $3 \%$ & $3 \%$ & $0 \%$ & $1 \%$ & $2 \%$ & $4 \%$ & $5 \%$ & $1 \%$ \\
\hline GHP & $7 \%$ & $5 \%$ & $1 \%$ & $2 \%$ & $13 \%$ & $13 \%$ & $9 \%$ & $4 \%$ & $0 \%$ & $3 \%$ & $1 \%$ & $0 \%$ & $10 \%$ & $10 \%$ & $1 \%$ \\
\hline
\end{tabular}

事務所、店舗、飲食では、9 つのゾーニング区分に等しく面積を配 置した。

\section{(5) 断熱の有無}

断熱対策については、北海道や東北の業務建築を除き 3031 31)、規模 によらず $20 \%$ 未満の採用率であることが報告されている ${ }^{32)}$ 。

本研究では建築ストックの平均的な断熱実施率を $20 \%$ とし、断熱 を採用している建物は $20 \mathrm{~mm}$ の硬質ウレタンフォーム $(0.028 \mathrm{~W} / \mathrm{m}$ $\left.\cdot{ }^{\circ} \mathrm{C}\right)$ を外壁に導入するものと設定した。

（6）省エネルギー手法

省エネルギー手法については第 2 節で集計した省エネルギー手法 の採用実態に基づいて $5 つ の$ 水準と各水準の床面積比率を算出した。 各水準は水準 1 が省エネルギー手法の採用がない建築、水準 5 は調 查対象の 5 つ寸べての省エネルギー手法を採用している建築とし、 水準が上がるに従って省エネルギー手法の採用数が増えるように設 定した。ただし、各水準で採用される省エネルギー手法は第 2 節に 示した省エネルギー手法の組み合わせについて、比率が高いものか ら選択した。用途別・規模別の省エネルギー水準に含まれる省エネ ルギー手法および床面積の比率を図 8 に示す。ただし、飲食施設が 主用途（最も延床面積に占める比率が高い用途）であるサンプルが
少なかったことから、店舗、飲食の集計においては、第 2 節で用い た商業施設のデータを共通のサンプルとして用い、表 2 に示した各 用途の規模区分で整理した。図 8 では紙面の都合上飲食施設の結果 を割愛している。次の熱源システムの結果でも同様である。

\section{（7）熱源システム}

建築の用途別・規模別に空調熱源システムの採用比率を集計した。 データのサンプルは省エネルギー手法の採用状況の把握に用いた空

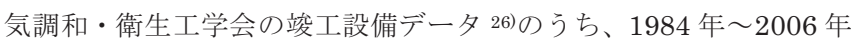
に竣工された事務所 2,339 件、商業 684 件、宿泊 1,003 件、医療 1,262 件である。集計手順を図 9 に説明する。サンプルデータは冷熱源機 器、温熱源機器の種類と機器別の容量が集計されている。まず、こ のデータに基づいて最も容量の大きい泠熱源機器、温熱源機器を抽 出した。次に、この主たる冷熱源機器・温熱源機器種類、加えて、 コージェネレーションシステム、蓄熱システムの有無についてす心゙ ての組み合わせを列挙し、各組み合わせの採用件数の比率を用途 別・規模別に算出した。この結果から、採用率の高い 8 種（表 4) の熱源システムに集約し、その採用率の比率を算出した。用途別の 集計結果を表 4 に示す。 


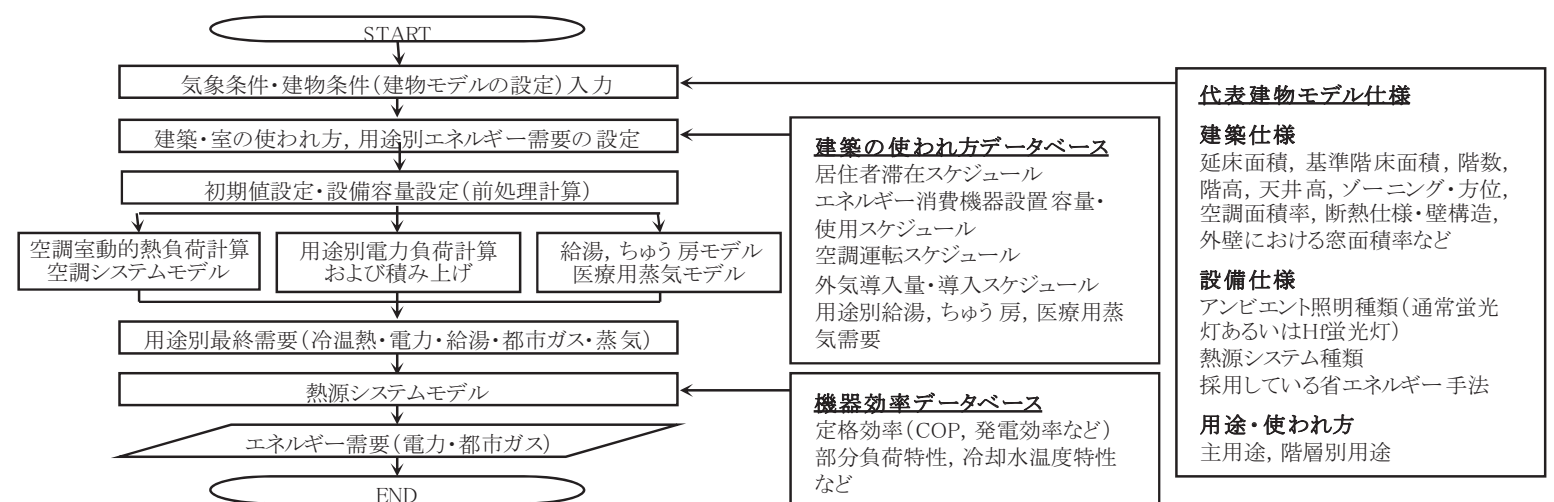

図 10 シミュレーションモデルの計算フローとデータベース
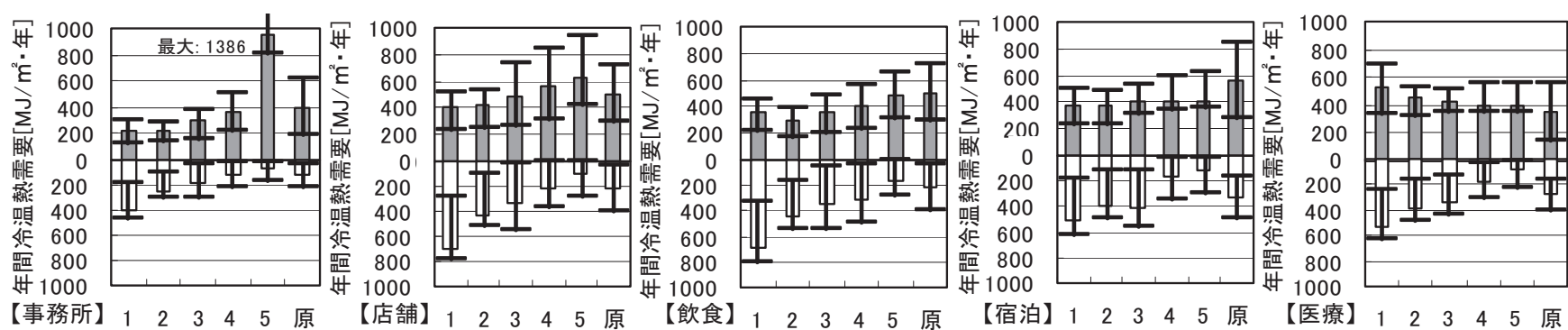

図 11 冷温熱需要推計結果（用途別・規模別：横軸の 1 から 5 の数字は規模区分 CL の数字、原は原単位を示す。上は冷熱、下は温熱)

\section{2 代表建物モデルによる原単位推計に用いるシミュレーション モデル}

図 10 に代表建物モデルの情報を入力条件として、エネルギー需 要（電力・都市ガス）を推計するシミュレーションモデルの計算手 順とデータベースの構成を示す。代表建物モデルは建築の形状（延 床面積・基準階床面積など)、壁などの部材の構造、基準階のゾーニ ングや方位、壁面における空面積、建築設備仕様（採用している熱 源システム、省エネルギー手法の種類、機器効率)、加えて、主用途 と階層別の用途を与える。建物類型別の代表建物モデルの設定は前 節に示したとおりであり、それ以外の要素は文献 4)5)参考に設定し た。階層別の用途に応じて居住者や室内のエネルギー消費機器の密 度やスケジュール、室内環境の維持に求められる空調スケジュール、 外気導入量などは各種文献に基づいて設定し、データベースとして モデルに組み込んでいる注1)。シミュレーションモデルでは、これら の条件に基づいて、冷温熱需要、電力需要 33 、給湯需要注 2)、ちゅ う房用エネルギー需要注 3 、 、医療用蒸気需要注 4) 1 時間タイムステ ップで算出し、熱源システムモデル（分散型電源を含む）によって 各最終需要を満足するために消費される電力量、都市ガス量を算出 する。ただし、前処理計算として、空調熱負荷の最大負荷計算など を行い、設備容量を設定している。

\section{3 建物類型別エネルギ一需要原単位の推計結果}

以上より得られた代表建物モデルを入力条件として、3．2 節に 説明したシミュレーションモデルを用い、建物類型別のエネルギー 需要（電力・都市ガス）を算出した。この結果を原単位化し、各建 物類型のエネルギー需要原単位として用いる。

図 11、図 12 に大阪市の業務建築を想定して建物類型別に算出し た用途別最終需要（冷温熱、電気）を示す。結果は用途別・規模別 に集計した值 (用途・規模以外の要素について重夕付け平均して算 出した）と最大值、最小值、参考值として過去の研究でまとめられ
たエネルギー需要原単位の上限值、下限值を示寸。この参考值デー 夕は平野ら ${ }^{34}$ ) がレビューした文献 10 件（冷温熱需要の掲載があっ た文献のみ） と空気調和・衛生工学会関西地区建物エネルギー消費 実態調查研究会 ${ }^{35)}$ のから作成したものである。推計結果は既存の原 単位の上限と下限の間にあり、おおむ称実態に反するものではない と考えられる。推計結果は原単位と近い值をとっているが、規模が 大きくなるにつれて温熱需要が小さくなり、冷熱需要が大きくなる 傾向がみられるなど、規模・用途に応じて特徵のあるエネルギー需 要が算出されている。事務所の規模区分 CL5 の電力需要、冷熱需要 が突出した数字となった理由は代表建物モデルにおいて電算機室を 想定したためである。既往研究でまとめられている電算機事務所の 冷熱需要原単位の上限は $2,541 \mathrm{MJ} / \mathrm{m}^{2}$ ・年、下限は $544 \mathrm{MJ} / \mathrm{m}^{2}$ ・年で あり、電算機室が入居している事務所ビルのエネルギー需要として は妥当なものであると考えられる。しかし、寸心゙ての用途において 原単位データに大きな幅がみられ、実態を反映した推計が得られて いると判断しにくい。建物単位のエネルギー消費実態調査に基づく 推計精度の検証を今後の課題とする。

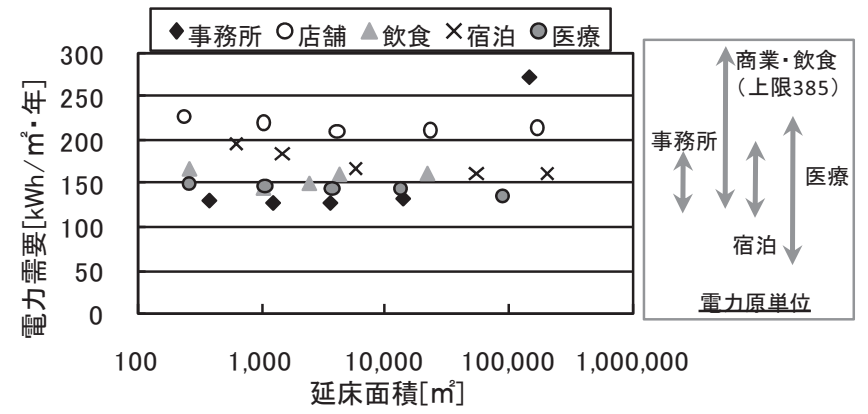

図 12 電力需要推計結果（図右の矢印は原単位の上限、下限を示寸）

\section{4 大阪市民生業務部門エネルギー需要の推計}

3. 3 節で求めた原単位を各類型のストック床面積にかけあわせ、 
類型別にエネルギー需要合計值を推計した。それらを足し合わせ、 大阪市業務部門のエネルギー需要（電気・都市ガス）を算出した。 図 13 に推定值および電力、都市ガスの統計值を示す。電力の統計 值は 2001 年における関西電力の業務用、小口、従量電灯 B 電力販 売量の実績值の合計 ${ }^{36)}$ 、都市ガスも同年の大阪ガスの商業、医療、 公用の都市ガス販売量実績值合計 $\left.{ }^{36}\right)$ とした。ただし、高効率照明の シェアについて利用可能なデータがなかったことから、室内の照明 器具として普通蛍光灯を仮定した場合（図 13 横軸では「高効率照 明なし」と表示)、高効率照明を仮定した場合（図 13 横軸では「高 効率照明」と表示) の両方の結果を示している。現在の高効率照明 の普及状況を勘案すると、エネルギー需要の推計值は両データの中 間付近に位置すると考えられる。建物類型モデルによる推計值を統 計値と比較すると、「高効率照明なし」の場合、電力は統計值よりも $1 \%$ 、都市ガスは $2 \%$ 大きい。「高効率照明」を仮定した場合、電力 は統計值よりも $8 \%$ 、都市ガスはほぼ統計值と等しくなる。都市ガ スにも変化が生じている理由は高効率照明の普及によって冷温熱需 要が変化するためである。図 14 に電力、都市ガス需要の内訳（最 終用途別，建物用途別）を示寸。

推計值において誤差が生じ得る要因は多数あるが、特に、商業、 飲食施設の冷凍冷蔵用のエネルギー消費など、本研究で十分にモデ ル化できていないエネルギー消費が存在することや、遊興施設や運 動施設など、多様なエネルギー消費形態を考慮できていないことな どが誤差要因としてあげられる。また、本研究では LP ガスや重油 などのエネルギー源を考慮していない。特にちゅう房用エネルギー はす心゙て都市ガスであるとしているなど現実を反映していない部分 もある。エネルギー消費実態データとの検証や精度の向上は今後の 課題とする。

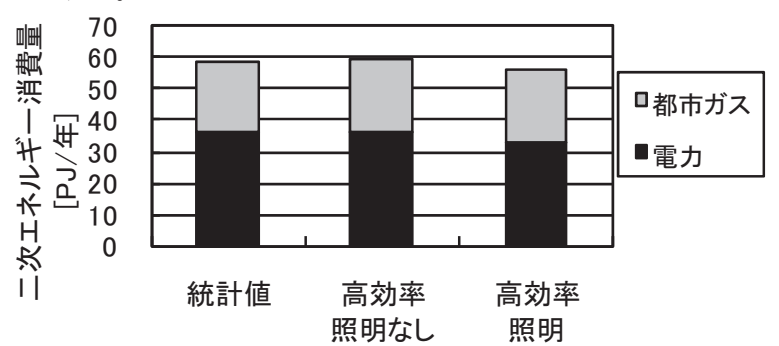

図 13 大阪市業務部門エネルギー需要（電力・都市ガス）推計結果

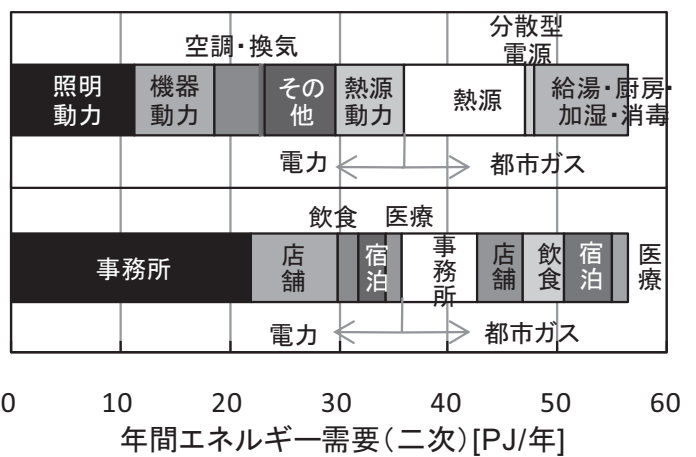

図 14 年間エネルギー需要 (二次) の内訳

（上：最終用途別，下：建物用途別）

\section{4. 業務建築における二酸化炭素排出量削減方策に関する検討}

建築ストックの集積状況、省エネルギー手法の採用状況をふまえ て、トップランナー熱源機器の普及、照明の高効率化、断熱強化、 省エネルギー手法の普及による二酸化炭素排出量削減ポテンシャル
を定量化する。以下では高効率照明の普及率をゼロとした場合の推 計值 (4,411 千トン $\mathrm{CO}_{2} /$ 年) をベースケースとする。なお、電気、 都市ガス $(13 \mathrm{~A})$ の二酸化炭素排出係数 37 として、 $0.338 \mathrm{~kg}-\mathrm{CO}_{2} / \mathrm{kWh}$ 、 $0.0506 \mathrm{~kg}-\mathrm{CO}_{2} / \mathrm{MJ}$ (発熱量 $41.1 \mathrm{MJ} / \mathrm{Nm}^{3}$ ) を用いた。

\section{（1） Hf 蛍光灯、トップランナー熱源機器の普及}

ここでは比較的成り行きで達成されやすいと考えられる普通蛍光 灯 $(70 \mathrm{~lm} / \mathrm{W})$ の $\mathrm{Hf}$ 蛍光灯 $(100 \mathrm{~lm} / \mathrm{W})$ 一の置き換え、トップラン ナ一熱源機器の普及を想定し、二酸化炭素排出量の削減ポテンシャ ルを示す。表 6 にベースライン推計に用いた熱源機器 COP とトッ プランナー熱源機の COP を示す。

図 15 に結果を示す。なお、結果は規模別に算出し、積み上げた 結果を表示している。棒グラフ上の数字は削減率を表す。図からト ップランナー熱源機器の普及、Hf 蛍光灯の普及はともに 7\%〜 $8 \%$ と大きな二酸化炭素排出量の削減をもたらすと考えられる。

表 6 熱源機器 $\mathrm{COP}$ の設定

\begin{tabular}{|c|c|c|c|}
\hline \multicolumn{2}{|l|}{ 熱源機器 } & ベース & トップランナー \\
\hline \multicolumn{2}{|l|}{ ターボ冷凍機 } & 4.50 & 6.00 \\
\hline \multirow{2}{*}{$\begin{array}{l}\text { 空気熱源ヒートポン } \\
\text { プ }\end{array}$} & 冷房 & 2.89 & 3.00 \\
\hline & 暖房 & 3.12 & 3.24 \\
\hline \multicolumn{2}{|l|}{ 吸収式冷温水機 } & 1.00 & 1.30 \\
\hline \multicolumn{2}{|l|}{ ガスボイラ [HHV] } & 0.83 & 0.83 \\
\hline \multirow{2}{*}{$\begin{array}{l}\text { ビルマルチ式 } \\
\text { 空調システム }\end{array}$} & 冷房 & 2.60 & 3.00 \\
\hline & 暖房 & 3.20 & 4.00 \\
\hline \multirow{2}{*}{$\begin{array}{l}\text { ガスエンジン駆動 } \\
\text { ヒートポンプ }\end{array}$} & 冷房 & 0.95 & 1.45 \\
\hline & 暖房 & 1.19 & 1.59 \\
\hline
\end{tabular}

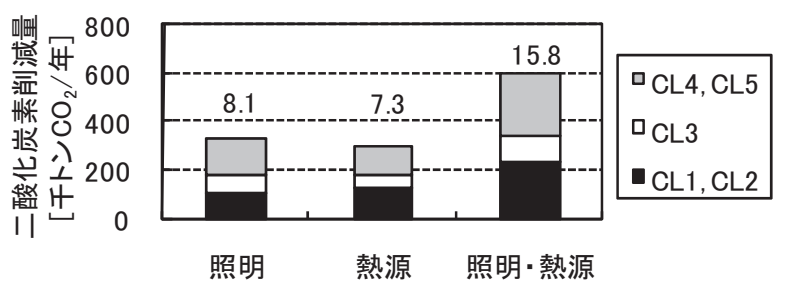

図 15 二酸化炭素排出削減ポテンシャルの推計

（Hf 蛍光灯、トップランナー熱源機器の普及による効果）

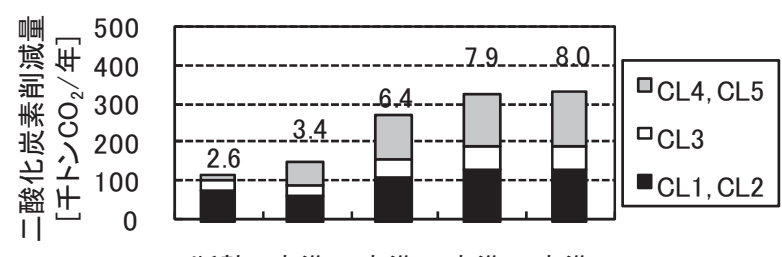

断熱 水準1 水準2 水準3 水準4

図 16 二酸化炭素排出削減ポテンシャルの推計 （断熱強化および省エネルギー手法の段階的普及 (右 4 つの結果)）

\section{（2）断熱強化および省エネルギーの推進}

ここでは断熱強化および省エネルギー手法の普及によって得られ る二酸化炭素排出量のポテンシャルを推計する。省エネルギー水準 のシェアを 4 段階で変更し、省エネルギー手法の普及をモデル化し た。第 1 段階では、水準 1 (省エネルギー手法の採用なし) の建築 の比率をゼロとし、水準 2 を採用している建築の比率をベースケー スにおいて水準 1 を採用している建築の比率とした。同様に、水準 3、水準 4 の建築の比率を、それぞれベースケースにおける水準 2、 水準 3 の比率とした。ただし、水準 5 はベースケースにおいて水準 4、水準 5 を採用している建築の比率の合計とした。第 2 段階から 第 4 段階でも同様に水準をひとつずつ増加させ、第 4 段階ではす心゙ ての建築が水準 5 となる設定とした。 
結果を図 16 に示す。断熱強化による削減ポテンシャルは、規模 区分 3 以下の中小規模建築での対策導入の寄与が大きい。この結果 から、中小規模建築（特に、省エネルギー法の対象ではない 2,000 $\mathrm{m}^{2}$ 未満の建築）における断熱性向上が重要であると考えられる。

省エネルギー手法の推進については、今回考慮した手法は空調関 連のものに限定されているにも関わらず、Hf 蛍光灯やトップランナ 一熱源機器の普及と同等の削減ポテンシャルがあることがわかった。 経年劣化などの影響により熱源システムの効率が想定したよりも 低い場合、ここで示した削減量はさらに大きくなる。

\section{（3）対策の複合効果}

ここでは Hf 蛍光灯の普及、断熱強化、トップランナー熱源機器 の普及、省エネルギー手法の普及によって得られる複合的な二酸化 炭素排出量削減ポテンシャルを推計する。結果を図 17 に示す。図 から現在利用可能な技術によって $30 \%$ の二酸化炭素排出量が削減 可能であることがわかる。この削減ポテンシャルの約 6 割を規模区 分 CL1 CL3 の中小規模建築が占める。

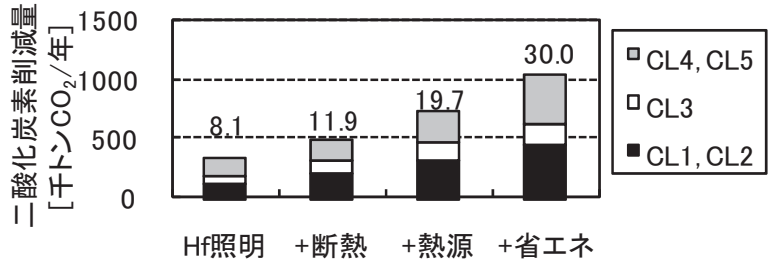

図 17 二酸化炭素排出削減ポテンシャルの推計 (各対策の複合効果)

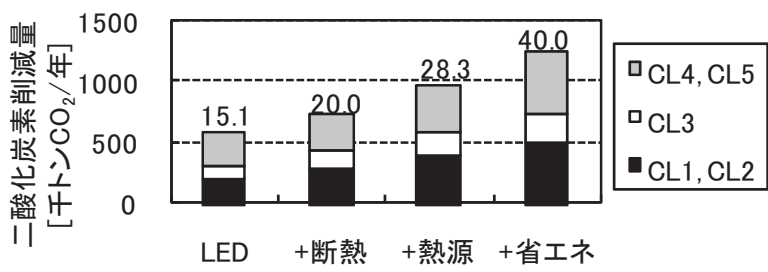

図 18 二酸化炭素排出削減ポテンシャルの推計 （LED 照明の普及と各種対策の複合効果）

\section{（4）LED の実用化による削減ポテンシャル}

照明器具では将来技術として現在使用されている蛍光灯と比較し て 2 倍程度の発光効率を持つ LED (Light Emitting Diode) 38)の実 用化が期待されている。ここでは、LED の発光効率を $150 \mathrm{~lm} / \mathrm{W}$ と して二酸化炭素排出量の削減ポテンシャルを推計した。ただし、応 用範囲は天井照明のみとし、店舗で用いられるディスプレイ用の照 明などに変化は起こらないものとした。結果を図 18 に示す。

LED 照明による二酸化炭素排出量の削減ポテンシャルは $15 \%$ に 達する。その他の手法との組み合わせにより $40 \%$ の削減が可能とな る。この結果は民生業務部門にいて $50 \%$ を超える大幅な二酸化炭素 排出量の削減を実現する可能性を示唆するとともに、大規模な削減 のためには多種多様な対策の導入が不可欠であることを示す。特に、 断熱強化による二酸化炭素排出量削減効果が $5 \%$ と単独で断熱強化 を行う場合よりも高い効果を示しているように、建築内における発 熱の減少など、今後の数十年間で生じうる変化を考慮して長期的に 建築ストックを転換していくことが重要であると考えられる。

\section{5. まとめ}

本論文では、日本の業務建築における温暖化対策の検討を目的と
して建築ストックの集積状況、省エネルギー手法の採用実態を調査 するとともに、建築仕様、省エネルギー手法、熱源システムなどの 設備仕様、建築の使われ方といった建築のエネルギー需要に大きな 影響を及ぼす要素の分布を反映し、都市スケールでエネルギー需要 を推計するモデルの構築手順を示した。本論文では大阪市の業務建 築を対象としてエネルギー需要モデルを開発し、今後の二酸化炭素 排出量の削減方策について検討した。得られた知見を以下に示寸。

・ 業務建築全体に占める中小規模建築の割合は非常に大きい。東 京都、大阪市、名古屋市では $2,000 \mathrm{~m}^{2}$ 未満の建築がストック全 体の $30 \%$ 40\%、1 万 $\mathrm{m}^{2}$ 未満であれば $60 \%$ 70\%を占める。

・ 省エネルギー手法の採用状況については、建築規模、用途、熱 源システムの種類 (セントラル空調方式か個別分散型空調方式) に応じて省エネルギー手法の採用状況が異なり、業務建築ス卜 ックの $50 \%$ 以上を占める中小規模建築では省エネルギー手法の 採用数が小さいことが明らかになった。

・高効率照明 (Hf 蛍光灯、LED) やトップランナー熱源機器の普 及などエネルギー消費機器の高効率化は大きな二酸化炭素排出 量削減ポテンシャルを持つ。しかし、今後半世紀間で $50 \%$ を超 える削減を実現するためには不十分であり、断熱強化や空調関 連の省エネルギー手法の導入など、個々の建築での省エネルギ 一の推進が不可欠である。中小規模建築は全二酸化炭素排出量 削減ポテンシャルの約 6 割を占める。

・ 今後照明器具における高効率化が進む場合、空調室内の内部発 熱の減少によって断熱強化による二酸化炭素排出削減ポテンシ ヤルは増加する。二酸化炭素排出量を大幅に削減するためには、 この例のように長期的な視点で建築ストックの転換を考えてい くことが有効である。

\section{謝辞}

本研究は日本学術振興会科学研究費補助金基盤研究 (B) 課題番号 18360273(代表者：下田吉之)ならびに若手（B）課題番号 20760409（代表： 山口容平）の助成を受けて行われたものである。本研究の遂行にあたり、山 口大学福代和宏准教授、大阪市、名古屋市、東京都の自治体関係者各位、ま た、浅井崇志君、石垣泰君、岩井良真君、橋本早紀君に多大なご支援を賜り ました。ここに記して謝意を表します。

注

注 1）事務所の設定は文献 33)39）、店舗、飲食、医療は文献 40)、宿泊施設は文 献 41)に基づいて設定した。

注 2）事務所ビル、飲食ビル、宿泊施設、医療建築について給湯需要を考慮した。 事務所ビルは村川ら ${ }^{42}$ の実測結果から冬期 4.5、夏期 4.0 リットル/日・人とした。 飲食ビルについては、高田ら ${ }^{43}$ の実測結果に基づいて、飲食店舗面積当たり 7.3 リットル $/ \mathrm{m}^{2}$ ・日とした。ともにスケジュールは人員在室率に比例するものとして

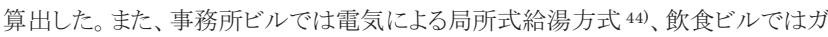
ス式 ${ }^{45)}$ の給湯器を想定した。宿泊施設では一人当たりの日積算使用湯量として 宿泊客一人当たり 100 リットル/日・人 46 )、加えて、供用部の床面積(客室・店舗を 除く面積とした) 当たり 50 リットル/日・ $\mathrm{m}^{2}{ }^{400}$ の給湯需要を想定した。医療施設で は宮崎ら ${ }^{47}$ による部門別の給湯需要の実測結果から病棟部での需要 42.0 リット ル/日・床、ちゅう房での需要 46.3 リットル/日・床、病棟、ちゅう房を除くその他の 部門での需要 0.5 リットル / ・ $\mathrm{m}^{2}$ (床面積) が生じるものとした。宿泊施設、医療 施設の給湯スケジュールは文献 40)より与えた。給湯はいずれもボイラにより行う ものとした。以上より得られた給湯需要と日平均給湯水温と上水温度の温度差、 水の比熱をかけ合わせ、給湯用のエネルギー需要として定量化する。

注 3）飲食用途では、村川ら ${ }^{48}$ の実測結果をもとにちゅう房面積当たりのガス消費 量 (夏期 $16 \mathrm{MJ} / \mathrm{m}^{2}$ ・日、中間期・冬期 $19 \mathrm{MJ} / \mathrm{m}^{2}$ ・日)を用いた。ただし、本モデル では飲食店舗の延床面積の $20 \%$ \%゙ちゅう房面積であるとし、すべてのちゅう房が ガス調理器具を使用していることを想定している。宿泊施設では、文献 49)から宴 会場面積当たりのちゅう房ガス消費量の平均值、 $6.66 \mathrm{~m}^{3} / \mathrm{m}^{2}$ ・月(宴会場面積当 
たり)を原単位として用いた。医療施設では、文献 50)のちゆう房におけるガス使 用量実績值 (一食当たりの都市ガス使用量平均值)、 $708 \mathrm{~kJ} /$ 食 $\left(0.0154 \mathrm{~m}^{3} /\right.$ 食)を 採用し、入院患者数の 3 倍を一日の食数とし、都市ガス消費量を算出した。

注 4) 病院における蒸気負荷は冷温熱、加湿、給湯以外に医療用(医療用の滅菌、 洗浄、洗濯など)の蒸気需要がある。本研究では河村ら ${ }^{51)}$ によるある病院の医療 用ガス消費量の測定結果を原単位化し、得られた $0.25 \mathrm{~m}^{3} / \mathrm{m}^{2}$ ・月を医療施設にお ける滅菌、洗浄、洗濯のための蒸気需要として与えた。また、医療建築では蒸気 加湿式で湿度調整を行うものとし、空調システムモデルにおいて加湿用蒸気需 要を算出している。

\section{本研究に関する既往発表論文}

1）下田吉之, 山口容平, 石垣泰, 水野稔: 民生業務部門における温暖化対策 のデザイン：第 1 報 建築ストックの集積および省エネルギー手法採用状況 の調査, 日本建築学会大会学術講演梗概集. D-1, pp. 873-874, 2007.7

2) 山口容平, 下田吉之, 石垣泰, 水野稔: 民生業務部門における温暖化対策 のデザイン：第 2 報 省エネルギーポテンシャルの推計, 日本建築学会大会 学術講演梗概集. D-1, pp. 875-876, 2007.7

\section{参考文献}

1）資源エネルギー庁:平成 18 年度「省エネルギー対策実態調査」報告書, 2007.3

2）小松幸夫, 島津護: 竣工記録に基づいた事務所建物の寿命調査, 日本建築 学会計画系論文集, No. 565, pp. 317 322, 2003.3

3）石田武志: 業務建物に導入される地球温暖化対策の相互効果評価モデルの 構築, 環境情報科学論文集, Vol. 21, pp. 625 630. 2007

4) 日本建築設備土協会空気調和設備シミュレーション研究会: 国内の空調装置 シミュレーションプログラムの比較, 空気調和・衛生工学, No.58-7, pp. 683 696, 1984.7

5) 滝沢博: 標準問題の提案 (オフィス用標準問題), 日本建築学会環境工学委 員会熱分科会第 15 回熱シンポジウム, pp. 35 42, 1985

6) Shorrock, L.D. and Dunster, J.E. : The Physically-based Model BREHOMES and Its Use in Deriving Scenarios for the Energy Use and Carbon Dioxide Emissions of the UK Housing Stock, Energy Policy, Vol. 25, pp. 1027 1037, 1997. 10

7）岩船由美子, 山地憲治: 業務用建物における各種省エネルギー施策の総合 的評価, 電気学会論文誌 B, Vol121, No.5. pp. 581 589, 2001. 5

8) Petersdorff, C. Boermans, T. and Harnisch, J.: Mitigation of $\mathrm{CO}_{2}$ Emissions from the EU-15 Building Stock, Beyond the EU Directive on the Energy Performance of Buildings, Environmental Science Pollution Research, Vol. 13, No. 5, pp. 350 358, 2006. 9

9) Huang J. Akbari H. Rainer L. and Ritschard R:481 prototypical commercial buildings for 20 urban market areas, Lawrence Berkeley Laboratory, LBL-29798, 1991. 4

10) Boardman, B.: Examining the carbon agenda via the $40 \%$ House scenario. Building Research and Information, Vol. 35, No. 4, pp. 363 378, 2007. 6

11) Shimoda, Y. Fujii, T. Morikawa, T. and Mizuno, M. : Residential End-use Energy Simulation at City Scale, Building and Environment, Vol. 39, pp. 959 967, 2004. 8

12) Clinch, J.P. Healy, J.D., King, C: Modelling Improvements in Domestic Energy Efficiency, Environmental Modelling and Software, Vol. 16, Iss. 1, pp. 87 106, 2001. 1

13) Clarke, J.A et al.: Using Simulation to Formulate Domestic Sector Upgrading Strategies for Scotland, Energy and Buildings, Vol. 36, pp. 759 770, 2004. 8

14）柳原隆司, 古越一三雄, 松縄堅, 野原文男, 伊香賀俊治, 近本智行, 長瀬 修: 東京都における業務用ビルの省エネルギー対策とその削減効果 (その1) 省エネルギー対策の波及効果と推進方法の検討, エネルギー資源学会, 第 17 回エネルギーシステム・経済・環境コンファレンス講演論文集, pp. 331 336, 2001.1

15）中野幸夫, 占部亘, 古賀登志雄, 濱田憲一, 和手俊明, 高橋淳一, 井上裕 光: 新築事務所ビルの節電・節水技術の費用対効果, 電力中央研究所報告 (研究報告:T02035), pp. 1 16, 2003.4

16）新谷圭右, 伊香賀俊治, 村上周三, 花木啓祐, 津田公平:建築・都市のサス テナビリティに関する研究(その 1 ) : 事務所ビル起因 $\mathrm{CO}_{2}$ 排出量の超長期予 測モデルの開発, 日本建築学会大会学術講演梗概集. D-1, 環境工学 I, pp. 1011 1012, 2007.7.

17）川久保俊, 新谷圭右, 伊香賀俊治, 村上周三, 花木啓祐, 津田公平:建築・ 都市のサステナビリティに関する研究(その 2) : 事務所ビル起因 $\mathrm{CO}_{2}$ 排出量 の 2050 年までの都道府県別予測, 日本建築学会大会学術講演梗概集. D-1, 環境工学 I, pp. 1013 1014, 2007.7.

18）石田武志, 森俊介: 地域の気候特性を考慮した業務建物における空調機器 の容量・稼動条件決定モデルに関する研究, 電気学会論文誌, Vol. 125C, pp. $1522 \sim 1529,2005.10$

19）外岡豊, 石田武志, 深澤大樹, 金本圭一朗:日本の業務部門における $\mathrm{CO}_{2}$
排出削減シナリオ, エネルギー・資源学会第 23 回エネルギーシステム・経済・ 環境コンファレンス講演論文集,pp. 21 24, 2007.1.

20）伊香賀俊治, 村上周三, 加藤信介, 白石靖幸:我が国の建築関連 $\mathrm{CO}_{2}$ 排出 量の 2050 年までの予測：建築・都市の環境負荷評価に関する研究，日本 建築学会計画系論文集, No. 535, pp. 53 58, 2000.9.

21）東京都都市整備局:平成 13 年度土地利用現況調査, 2001

22）東京都都市整備局: 平成 14 年度土地利用現況調査, 2002

23）大阪市計画調整局:平成 12 年土地利用現況調查, 2000

24) 名古屋市住宅都市局: 平成 13 年度建物用途現況データ, 2001

25）(財) 日本エネルギー経済研究所計量分析ユニット:エネルギー・経済統計要 覽 (2006 年版), 2006. 2

26）(社)空気調和・衛生工学会: 竣工設備調査用紙一覧 1984 2006

27）（社)建築設備士技術者協会:ELPAC2005, 2005

28）日本建築学会:建築設計資料集成[余暇・宿泊]第 2 章宿泊, pp. 83 145, 2001. 5

29）日本建築学会:建築設計資料集成[福祉・医療], pp. 1 166, 2001. 5

30）日本建築学会北海道支部建築のエネルギー消費調査研究委員会: 札幌市 における業務用建物のエネルギー消費実態調查—建築のエネルギー消費調 査研究委員会報告一, 2002.6

31）東北都市環境研究グループ:空気調和・衛生工学会東北支部および日本建 築学会東北支部環境工学部会助成研究, 東北地方における業務用建築の エネルギー消費実態調査, 2000.1

32）(財)省エネルギーセンター:平成 17 年度省エネルギー対策アンケート調査結 果, http://www.eccj.or.jp/swenqute/17/build.html, アクセス日:2007.2.10

33）山口容平, 下田吉之, 水野稔: 居住者の行動を基準としたオフィスビルの熱. 電力需要シミュレーションモデルの開発, 空気調和・衛生工学会論文集, No. 93, pp. 37 47, 2004.4

34）平野勇二郎, 外岡豊, 伊香賀俊治, 亀卦川幸浩, 藤沼康実, 下田吉之:民生 業務部門エネルギー消費原単位に関する各種資料の比較評価，日本建築 学会環境系論文集, No. 73, pp. 1331 1339, 2008. 11

35）空気調和衛生工学会関西地区建物エネルギー消費実態調査研究会: 関西 地区建物エネルギー消費実態調査報告書, 1997

36) 大阪市計画局調整部統計課編: 大阪市統計書平成 13 年度版, 2002.3

37）環境省: 温室効果ガス排出量算定・報告・公表制度における算定方法・排出 係数一覧, http://www.env.go.jp/earth/ghg-santeikohyo/material/ (2008.10.9 閲覧)

38) Optoelectronics Industry Development Association: Light Emitting Diodes (LEDs) for General Illumination, An OIDA Technology Roadmap Update, in: Roadmap Recommendations, pp. 4 23, 2002

39）羽山広文, 中里秀明, 木下学, 倉渕隆: 強制空冷機器を収容した電算機室の 高効率空調方式に関する研究, 日本建築学会計画系論文集, No. 494, pp. 29 36, 1997.4

40）財団法人 住宅・建築省エネルギー機構 (IBEC) : 建築物の省エネルギー基 準と計算の手引, 平成 9 年度版, 1997

41）岩㴊善美, 村上裕子, 東野達, 笠原三紀夫:ビジネスホテルにおけるエネルキ 一・環境負荷低減 第 1 報-冬期における客室内の電力消費の現状分析, 空 気調和・衛生工学会論文集, No. 92, pp. 57 64, 2004.1

42）村川三郎, 高田宏, 山根祐子: 事務所ビルにおける用途別使用水量・湯量の 解析: 時系列的水使用行為解析に基づく給水・給湯負荷算定法に関寸る研 究(第 1 報), 日本建築学会環境系論文集, Vol. 589, pp. 43 50, 2005.3

43）高田宏, 村川三郎, 田中篤:飲食店舗における給湯負荷の解析, 日本建築学 会環境系論文集, Vol. 616,pp. 59 65, 2007.6

44) 空気調和・衛生工学会:空気調和・衛生工学便覧第 13 版, 6 応用篇, 第 12 編空気調和応用, 第 2 章給排水衛生設備, 第 2 章 事務施設 pp. 459 469, 2001.

45）空気調和・衛生工学会:空気調和衛生工学便覧第 13 版, 6 応用篇, 第 12 編 空気調和応用, 第 1 章保険空調, 1.5 商業施設 pp. 200 209, 2001.

46）岩本靜男, 桑沢保夫, 田島昌樹, 宇梶正明, 前真之: 給湯設備における年間 消費エネルギーの予測に関する研究:第 1 報 ビジネスホテルの計量結果と $\mathrm{CEC} / \mathrm{HW}$ 計算結果の比較, 日本建築学会大会学術講演梗概集. D-1, 環境 工学 I, pp.409 410, 2006.7

47）宮崎綾,松本敏男, 工藤牧子, 小島龍也, 菅原志文:YU 病院における休日 の給湯量の実測調査, 日本建築学会大会学術講演梗概集. D-1, 環境工学 I, pp. 513 514, 2001.7

48）村川三郎, 篠原道正, 清田誠良, 越川康夫, 西名大作, 伊藤 博幸: 業務用 ちゅう房における各種調理機器の使われ方とエネルギー消費量の解析, 空気 調和・衛生工学会論文集, No. 69, pp. 61 73, 1998.4

49）空気調和·衛生工学会:空気調和衛生工学便覧第 13 版, 6 応用篇, 第 13 編 給排水衛生設備応用, 第 4 章保険空調, 宿泊・宴会施設, pp. 481 491, 2001.

50）空気調和・衛生工学会:空気調和衛生工学便覧第 13 版, 6 応用篇, 第 12 編 空気調和応用, 第 1 章保険空調, 1.7 医療施設 pp. 504 514, 2001

51）河村貢, 黒田英男, 三原一伸, 山内桂一:榊原記念病院の部門別エネルギ 一消費実態について—第一報：病院全体のエネルギー消費実態の概要, 日 本建築学会大会学術講演梗概集 D-2，環境工学 II, pp. 1383 1384, 2007. 7 